\title{
Experience of Introduction of Two Species of Eryngium in the North Caucasus
}

\author{
Shcherbakova Ekaterina Aleksandrovna, Eliseeva Lyudmila Mikhailovna, Konovalov Dmitry Alexeevich*
}

\section{Shcherbakova Ekaterina Aleksandrovna, Eliseeva Lyudmila Mikhailovna, Konovalov Dmitry Alexeevich*}

\section{Department of Pharmacognozy and botany, Pyatigorsk Medical and Pharmaceutical Institute, a branch of Volgograd State Medical University Ministry of Health of the Russian Federation, Pyatigorsk, 357532, Kalinina av.11, RUSSIA. \\ Correspondence}

Konovalov Dmitry Alexeevich

Department of Pharmacognosy and Botany, Pyatigorsk Medical and Pharmaceutical Institute, A branch of Volgograd State Medical University, Ministry of Health of the Russian Federation, Pyatigorsk, 357532, Kalinina AV.11, RUSSIA.

Phone no : +7 89283519349

E-mail: d.a.konovalov@pmedpharm.ru History

- Submission Date: 05-07-2018;

- Review completed: 14-08-2018;

- Accepted Date: 19-09-2018

DOI : 10.5530/pj.2018.6s.11

Article Available online

http://www.phcogj.com/v10/i6s

\section{Copyright}

(C) 2018 Phcog.Net. This is an openaccess article distributed under the terms of the Creative Commons Attribution 4.0 International license.

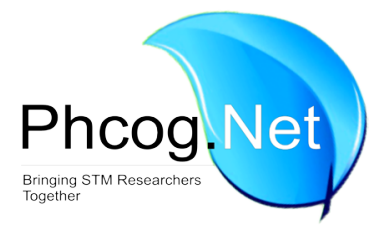

\begin{abstract}
The article gives recommendations on the cultivation of Eryngium caucasicum Trautv. and Eryngium planum L. in the Caucasus. Introduction: In Russia, grows about 20 species of Eryngium, in the Caucasus - 8 species. Materials and Methods: The subjects of the study were two species: Eryngium caucasicum Trautv. and Eryngium planum L. The main methods of research: field, observation, mathematical. Results: The seedlings appear on the 14-16 day. In the first year of vegetation, a rosette of leaves is formed. In September, the rosettes of leaves have a diameter of 35-39 cm. Plants of the second year of vegetation pass through all phases of development: Eryngium caucasicum Trautv. - for 180 days, Eryngium planum L. - for 160 days. Conclusion: Seeds should be sown in late autumn (late October - early November) or early spring (late February - beginning of March). Seeds are sown to a depth of $1-2 \mathrm{~cm}$, between rows $-50-60 \mathrm{~cm}$. Care of plants requires weeding from weeds and watering. Collection of seeds and fruits is recommended in August - September.

Key words: Eryngium, Eryngium caucasicum, Eryngium plan, Recommendations, Introduction.
\end{abstract}

\section{INTRODUCTION}

The genus Eryngium L. belongs to the family Apiaceae, which consists of about 300 species, species growing in the tropical, subtropical and temperate latitudes of the worldwide. ${ }^{1}$ Species of Eryngium L. are widespread in Central Asia, America, Central and South-Eastern Europe. In Russia, grows about 20 species, in the Caucasus - 8 species. ${ }^{2}$ Eryngium caucasicum Trautv. and Eryngium planum L. - perennial herbaceous plants. The aboveground and underground parts of these species contain terpenoids, saponins, flavonoids, phenolic acids, coumarins, polyacetylenes and other biologically active compounds. ${ }^{3-6}$ These substances determine diuretics, antispasmodic, antifungal, cytotoxic, antitubercular and stimulating properties..$^{7-8}$ Among the known species of the genus Eryngium, we studied two species: E. caucasicum Trautv. and E. planum L., which are characterized by a wide variety of active substances and use in folk medicine. ${ }^{9}$ Plants have a large vegetative mass, which is important when harvesting raw materials. Studies on the introduction of these species were carried out from 2014 to 2017. Some observational data for 2014-2016 are published in the press. ${ }^{10-11}$ In this paper, we propose the results of observations for 2017, taking into account climatic data and general recommendations for the cultivation of two species of the genus Eringium in the Stavropol Territory (the North Caucasus).

\section{MATERIALS AND METHODS}

Plains of the Stavropol Territory receive 120-125 kcal $/ \mathrm{cm}^{2}$ of solar radiation per year. The maximum temperature reaches $37-45^{\circ} \mathrm{C}$. The amount of rainfall is small, 170-180 mm per year. Seeds of Eryngium caucasicum Trautv. and Eryngium planum L. were harvested in various regions of Dagestan, Kabardino-Balkaria and the Stavropol Territory. Mature seeds were collected for research in August-September 2014. Seeds were placed in the soil in early spring (March) and late autumn (November). Seeds are small, 2-3 $\mathrm{mm}$ in length, sown to a depth of 1-2 cm, between rows - 50-60 $\mathrm{cm}$, since leaves can reach a diameter of $60 \mathrm{~cm}$. The main methods of research are: Observation, Field, Mathematical.

\section{RESULTS AND DISCUSSION}

Observations were carried out on plants of the first and second years of development. The species are propagated by seeds. In the first year, seeds were sown and the formation of a rosettes of leaves was observed. In 2017, spring seed sowing was carried out on March 30, when the air temperature was 12 degrees Celsius. Seedlings appeared on April 14-16. Rosettes of leaves began to form on May 4-6. The dynamics of rosettes growth, the number of formed leaves and temperature data in the first year of development are presented in Table 1. 


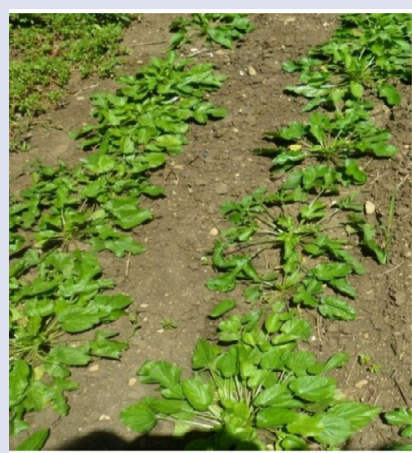

A

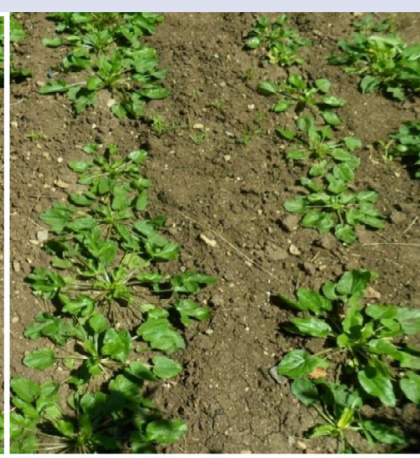

$\mathrm{B}$

Figure 1: Rosettes of leaves: A - Eryngium caucasicum; B - Eryngium planum.

According to the Table, that the formation of rosettes of leaves in the first year of development continues 60-70 days. During August, slightly increased the size of leaf rosettes. At the same time, air temperature has no special effect on the formation of rosettes. The diameter of the rosettes and the number of leaves in the Eryngium planum are somewhat smaller than in the Eryngium caucasicum (Figure 1).

In this state, the plants were before winter. In winter, some of the leaves die off, but in spring the new leaves grow back.

In 2017, the growth of plants of the second year began on March 8-9, when the air temperature was $4-9^{\circ} \mathrm{C}$. Rosettes of leaves formed in Eryngium caucasicum until April 30, in Eryngium planum - until May 12. Their dimensions were $58-60 \mathrm{~cm}$ and $47-54 \mathrm{~cm}$, respectively.

The results of observations on the phases of plant development in the second year of vegetation are presented in Table 2.

Plants in the second year of vegetation first form rosettes of leaves, then begin to develop shoots. The phase of budding is shown in Figure 2.

The duration of vegetation phases is presented in Table 3.

Such differences in the duration of developmental phases are explained by the different degree of branching of shoots. In Eryngium planum inflo-

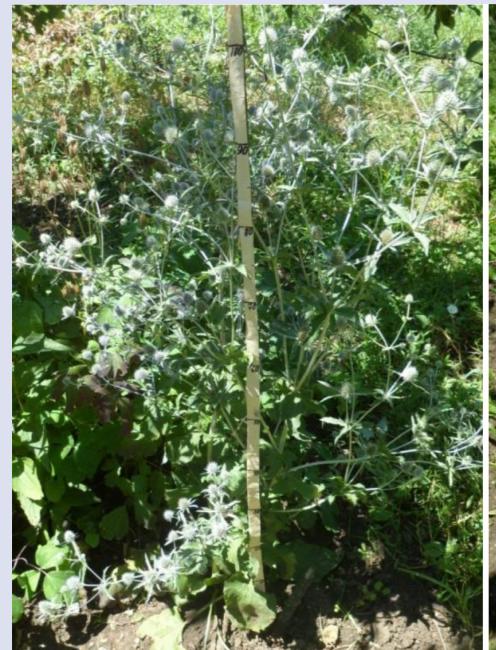

A

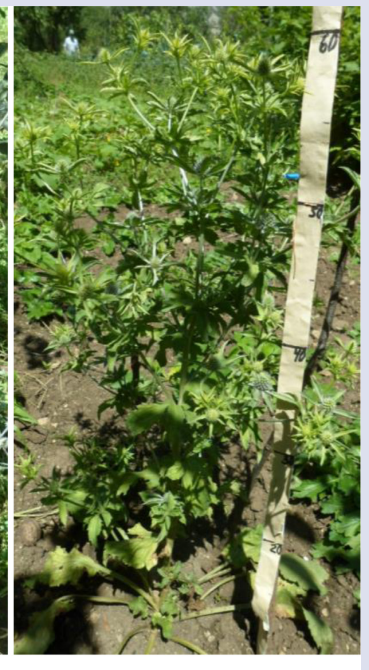

B
Figure 2: Plants in the budding phase: A - Eryngium caucasicum; $\mathrm{B}$ - Eryngium planum.

rescences less branched, more compact, Eryngium caucasicum forms a large number of lateral branches - the axes of inflorescences.

As a result of the study, it was found that when sowing seeds at the end of March it took 150-160 days to completely form a rosette of leaves in the first year of vegetation. Rosettes of leaves had a diameter of $35-39 \mathrm{~cm}$. In the second year of vegetation, the formation of new leaves and their growth began on March 8-9 at a temperature of $4-9^{\circ} \mathrm{C}$. The fruits of Eryngium planum ripened in August, and Eryngium caucasicum - in September. For the full development of plants, it took 120-140 and 160-180 days, respectively. Care of plants consisted of weeding from weeds and watering. In the absence of precipitation it is necessary to water 1-2 times a week. The spring-summer period of 2017 was characterized by a large amount of rainfall in April-June. Therefore, the plants of this year have grown to $120-140 \mathrm{~cm}$.

Observations in 2017 confirm the possibility of successful cultivation of two species of Eringium in the Stavropol Territory.

Table 1: Duration of vegetation of two species of Eringium in the first year of development.

\begin{tabular}{|c|c|c|c|c|c|}
\hline \multirow[t]{2}{*}{ Date of observation } & \multirow[t]{2}{*}{ Air temperature, ${ }^{\circ} \mathrm{C}$} & \multicolumn{2}{|c|}{ Eryngium caucasicum } & \multicolumn{2}{|c|}{ Eryngium planum } \\
\hline & & $\begin{array}{l}\text { Diameter of rosettes of } \\
\text { leaves, } \\
\mathrm{cm}\end{array}$ & Number of leaves & $\begin{array}{c}\text { Diameter of } \\
\text { rosettes of leaves, } \\
\mathrm{cm}\end{array}$ & Number of leaves \\
\hline 12.05 .17 г. & 17 & $3,5-9$ & $3-7$ & 7-9 & $3-4$ \\
\hline 19.05 .17 г. & 14 & $12-17$ & $8-11$ & $8-13$ & $3-5$ \\
\hline 26.05 .17 г. & 20 & $13-20$ & $20-23$ & $8-14$ & $3-5$ \\
\hline 01.06 .17 г. & 20 & $15-25$ & $22-25$ & $13-18$ & $4-5$ \\
\hline 08.06.17 г. & 28 & $19-27$ & $24-26$ & $14-19$ & $5-6$ \\
\hline 15.06 .17 г. & 22 & $21-29$ & $27-30$ & $15-20$ & $6-7$ \\
\hline 22.06 .17 г. & 20 & $22-30$ & $31-35$ & $17-20$ & $6-8$ \\
\hline 02.07.17 г. & 36 & $24-32$ & $34-43$ & $18-20$ & $7-8$ \\
\hline 11.07 .17 г. & 26 & $32-36$ & $37-48$ & $20-28$ & $7-8$ \\
\hline 20.07 .17 г. & 20 & $33-38$ & $37-48$ & $23-32$ & $7-8$ \\
\hline 08.09.17 г. & 24 & $36-39$ & $37-48$ & $26-35$ & $7-8$ \\
\hline
\end{tabular}


Table 2: Dynamics of shoots growth of two species of Eryngium.

\begin{tabular}{|c|c|c|c|c|c|}
\hline \multirow{2}{*}{$\begin{array}{c}\text { Date of } \\
\text { observation }\end{array}$} & \multirow[t]{2}{*}{ Air temperature, ${ }^{\circ} \mathrm{C}$} & \multicolumn{2}{|c|}{ Eryngium caucasicum } & \multicolumn{2}{|c|}{ Eryngium planum } \\
\hline & & Height of shoots, $\mathrm{cm}$ & Development phase & Height of shoots, cm & Development phase \\
\hline 06.05 .17 г. & 8 & $5-15$ & growth of shoots & - & rosette of leaves \\
\hline 08.05.17 г. & 20 & $25-40$ & growth of shoots & - & rosette of leaves \\
\hline 12.05 .17 г. & 17 & $35-49$ & growth of shoots & - & rosette of leaves \\
\hline 16.05 .17 г. & 10 & $48-67$ & growth of shoots & $7-22$ & growth of shoots \\
\hline 21.05 .17 г. & 23 & $50-90$ & growth of shoots & $18-35$ & growth of shoots \\
\hline 25.05 .17 г. & 14 & $51-96$ & growth of shoots & $27-47$ & growth of shoots \\
\hline 28.05 .17 г. & 18 & $60-98$ & growth of shoots & $40-62$ & beginning of budding \\
\hline 01.06 .17 г. & 20 & $80-105$ & beginning of budding & $40-63$ & budding \\
\hline 08.06 .17 г. & 28 & $94-125$ & budding & $74-87$ & budding \\
\hline 20.06 .17 г. & 20 & $112-134$ & budding & $93-109$ & budding \\
\hline 02.07.17 г. & 36 & $135-140$ & beginning of flowering & $100-115$ & beginning of flowering \\
\hline 11.07 .17 г. & 26 & $135-140$ & flowering & $100-115$ & flowering \\
\hline 16.07.17 г. & 27 & $135-140$ & flowering & $116-120$ & flowering \\
\hline 30.07 .17 & 25 & $135-140$ & flowering & $116-120$ & end of flowering \\
\hline 10.08 .17 г. & 29 & $135-140$ & end of flowering & $116-120$ & beginning of fruits ripening \\
\hline 18.08 .17 г. & 27 & $135-140$ & beginning of fruits ripening & $116-120$ & fruits ripening \\
\hline 08.09.17 г. & 24 & $135-140$ & fruits ripening & - & - \\
\hline
\end{tabular}

Table 3: Duration of vegetation phases of two species of Eringium in the second year of development (days).

\begin{tabular}{ccccccc}
\hline Species & $\begin{array}{c}\text { Rosettes of } \\
\text { leaves }\end{array}$ & $\begin{array}{c}\text { Growth of } \\
\text { shoots }\end{array}$ & Budding & Flowering & Fruits ripening & Total \\
\hline Eryngium caucasicum & 50 & $25-30$ & $25-30$ & 40 & $20-30$ & $160-180$ \\
Eryngium planum & 65 & $10-15$ & $15-20$ & $20-25$ & $10-15$ & $120-140$ \\
\hline
\end{tabular}

\section{CONCLUSION}

Thus, as a result of observations of the vegetation of two species of Eringium in the Stavropol Territory (the North Caucasus) during 2014-2017, we propose the following recommendations for their introduction:

1. Plants must be propagated by seeds.

2. Seed sowing should be done in late February - early March. In addition, you can sow in the autumn - in late October - early November.

3. Seeds are placed in the soil at a depth of $1-2 \mathrm{~cm}$, between rows $-50-60 \mathrm{~cm}$.

4. Make weeding and watering as necessary.

5. Chemical protection of plants from pests is not required.

6. Harvesting fruits and seeds in August-September.

\section{ACKNOWLEDGEMENT}

This research project was carried out with the assistance of the Fund for the development of research. The authors are grateful to the head of Pyatigorsk Medical and Pharmaceutical Institute V. L. Adgienko.

\section{CONFLICT OF INTEREST}

When performing this research conflicts of interest did not arise, since all of the authors have conducted research work comprehensively.

\section{REFERENCES}

1. Muckensturm B, Boulanger A, Farahi M, Reduron JP. Secondary metabolites from Eryngium species. Natural product research. 2010;24(5):391-7.

2. Czerepanov SK. Vascular plants of Russia and adjacent states (the former USSR). Cambridge University Press. 2007;992.

3. Erdem SA, Nabavi SF, Orhan IE, Daglia M, Izadi M, Nabavi SM. Blessings in disguise: a review of phytochemical composition and antimicrobial activity of plants belonging to the genus Eryngium. DARU Journal of Pharmaceutical Sciences. 2015;23(1):53

4. Conea S, Vlase L, Chirila I. Comparative study on the polyphenols and pectin of three Eryngium species and their antimicrobial activity. Cellulose chemistry and technology. 2016;50(3-4):473-81

5. Riekandeh SM, Mazandarani M, Ebrahimzadeh MA, Zargari M. Antioxidant activities of Eryngium caucasicum inflorescence. European review for medical and pharmacological sciences. 2016;20(5):946-9

6. Hashemabadi D, Kaviani B. Chemical constituents of essential oils extracted from the leaves and stems of Eryngium caucasicum Trautv. from Iran. Journal of Essential Oil Bearing Plants. 2011;14(6):693-8.

7. Nasuhova AM, Orobinskaya VN, Konovalov DA, Kuzmina U, Shchanukova EA. Natural polyacetylene compounds with antitubercular activity. Medical news of the North Caucasus. 2016;11(4):595-9.

8. Spiridonov NA, Konovalov DA, Arkhipov VV. Cytotoxicity of some Russian ethnomedicinal plants and plant compounds. Phytotherapy Research. 2005;19(5):428-32.

9. Ebrahimzadeh MA, Chitsaz Z, Shokrzadeh M, Ataie A, Ataee R. et al. Evaluation of Anticonvulsant Activities of Eryngium caucasicum with Maximal Electroshock and Kindling Model of Seizure in Mice. Iran J Psychiatry Behav Sci. 2017;11(1):e3571.

10. Eliseeva LM, Scherbakova EA, Konovalov DA, Galkin MA. Active parts and seed efficiency of Eryngium planum from Apiaceae family. Pharmacy and pharmacology. 2015:1(8):14-6.

11. Shcherbakova EA, Konovalov DA, Eliseeva LM. Possibility of Eryngium caucasicum and Eryngium planum introduction in the region of Mineralnye Vody, Caucasus. Aspirantskiy Vestnik Povolzhiya. 2017;1-2:221-7. 
GRAPHICAL ABSTRACT

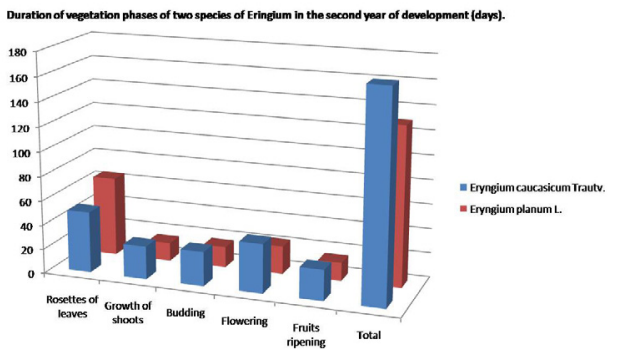

\section{SUMMARY}

- The article gives recommendations on the cultivation of Eryngium caucasicum Trautv. and Eryngium planum L. in the Caucasus. Seeds should be placed in the ground in late autumn (late October-early November) or early spring (late February-early March). Seeds are sown to a depth of 1-2 cm, between rows of $50-60 \mathrm{~cm}$. The seedlings appear on the 14-16th day. In the first year of vegetation, a rosette of leaves is formed. By the beginning of September, the rosettes of leaves have a diameter of $35-39 \mathrm{~cm}$. The plants of the second year are Eryngium caucasicum Trautv. Develop within 180 days and Eryngium planum L. - for 160 days. Care of plants is the removal of weeds and watering. Collection of seeds and fruits is recommended in August-September.

\section{ABOUT AUTHORS}

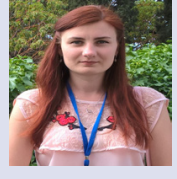

Shcherbakova Ekaterina Aleksandrovna: Postgraduate student at the Chair of Pharmacognosy, Department of Pharmacognosy and Botany Pyatigorsk medical-pharmaceutical Institute - branch FGBOU VO VolgGMU Ministry of health of Russia, RUSSIA. Research interests: Phytochemistry, Pharmacognosy.

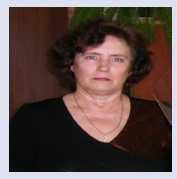

Eliseeva Lyudmila Mikhailovna: Candidate of Pharmaceutical Sciences, Senior Lecturer, Department of Pharmacognosy and Botany Pyatigorsk Medical-Pharmaceutical Institute - branch FGBOU VO VolgGMU Ministry of health of Russia, RUSSIA. Research interests: Study of the flora of the Caucasian Mineral Waters, Micro morphologic study of plants of the Caucasus.

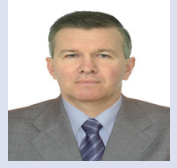

Konovalov Dmitryi Alexeevich: Doctor of Pharmaceutical Sciences, Professor, Department of Pharmacognosy and Botany Pyatigorsk, Medical-Pharmaceutical Institute - branch FGBOU VO VolgGMU Ministry of health of Russia, RUSSIA. Research interests: Phytochemistry, Pharmacognosy, Sesquiterpene lactones, Polyacetylene compounds.

Cite this article: Shcherbakova EA, Eliseeva LM, Konovalov DA Experience of Introduction of Two Species of Eryngium in the North Caucasus. Pharmacog J. 2018;10(6)Suppl:s59-s62. 